\title{
Earnings Management and Corporate Social Responsibility: Evidence from Islamic Banks in GCC
}

\author{
Dr. Sherif Ismail El-Halaby \\ Arabic open university - Kuwait branch
}

Dr. Mona Abd El-Hakim Ragab

Badr University

\begin{abstract}
:
The previous literature has drawn attention to the relationship between the financial reporting quality which measured by earnings management (EM) practices and commitment to social accountability or corporate social responsibility (CSR). As far as we know- no evidence about this association regarding to Islamic banking context which characterised by ethical; moral commitment and social accountability. Empirical evidence, however, provides inconclusive results regarding the direction of this association. Using simultaneous equations and longitudinal panel data analysis, we examine the bi-directional EM-CSRD relationship for 29 Islamic banks across Gulf Cooperation Council (GCC) region during 5 years (2012-2016). We demonstrate that, bi-directional EM-CSRD association is not significant. The insignificant findings between EM and CSRD suggest that social reporting for Islamic banks is not being manipulated to cover their EM practices. We provide implications for investors, analysts and regulators

Key words- Earnings management (EM), corporate social responsibility disclosure (CSRD),

Bi-directional association; Islamic banks, GCC
\end{abstract}

\section{Introduction:}

The Islamic banking/finance industries have progressively sliced out a considerable piece of the global financial market (Faraga et al., 2014). This is owing to their religious distinctiveness, Islamic banks (IBs) are more predicted to be socially responsible. IBs are also expected to perform the role of reallocating acquired wealth to carefully chosen investments, which contribute to the overall enhancement and well-being of the wider society (Faraga et al., 2014). It has been established that IBs practice the so called 'moral economy' which is a philosophy that explains the differences between religious and secular ethical reasons and back the enclosure of social and environmental aims 
in their investments policies (Belal et al., 2014). Furthermore, Islamic banks are more likely to observe economic and social advantages and to satisfy their Corporate Social Responsibility (CSR) including its disclosure (Faraga et al., 2014). Farook (2008) claims that disclosure offers evidence of the participation of IBs in social activities, thus earns legitimacy for their existence.

Banks around the world have been found to manage their earnings (e.g., Shen and Chih, 2005). Earnings management (EM) disables investors' ability to forecast banks' future cash flow accurately based on current financial information (Quttainah et al., 2013). Consequently, it increases information asymmetry problems between banks and investors and reduces banking sector stability (Chen and Hasan, 2008). EM is considered as an unethical behaviour due to; it may weaken the economy if the manipulation is not revealed; it misleads stakeholders and it may likely misrepresent the returns on investor (Obid and Demikha, 2011). EM has attracted much attention from both academics and practitioners in the last few years, arising as one of the major research in financial accounting and management (Shu \& Chiang, 2014). Despite this wealth of research, little is known about earnings management in Islamic banking industry.

Francis et al (2008) has proven that EM has a direct effect over the corporate reporting decisions. Jensen (2010) argues that, when board act as agents of the stakeholders, the strategic behaviour of CSR reporting practices can be regarded as an entrenchment initiated as a consequence of EM. Previous literatures have revealed a robust and significant association between CSRD and EM (Ibrahim et al., 2015; Grougiou et al., 2014; Ahmed et al., 2012). However, a little empirical work -to the best of our knowledge- has been undertaken to investigate the bi-directional association between CSRD and EM from an Islamic perspective (Ibrahima et al., 2015: Alsaadi et al., 2013) particularly in GCC despite the importance of this region on political and economic levels (Srairi, 2010).

In contradiction of this background and to filling this gap, we employ a sample of 29 Islamic banks in GCC region during a fiveyear period (2012-2016) to examine whether commitment to CSR activities has any association to the quality of financial reporting which is measured by EM. We estimate a simultaneous equations system by employing a two-stage least squares (2SLS) regression method to control for any endogeneity problems. We measure a bank's CSR commitment by a comprehensive index which 
contains universal as well as Islamic items which has been used in CSR research (e.g., Belal et al., 2014). We measure EM by using accruals and Cash flow from operations as a proxy for capturing bank managers' discretionary decisions to manipulate earnings. We choose these measures over the alternative, the restatement and fraud choices approach, since it is apparently more difficult to determine discretionary choices if the latter is used (Beatty et al., 2002).

This study is motivated by several factors. First; the main sizeable body of research related to Islamic banking has explained the general Islamic principles (Siddiqui, 2006); have discussed regulatory and supervisory challenges (Jobst and Andreas, 2007), efficiency (Belanes and Hassiki, 2012), characteristics and profitability (Beck et al., 2013), soundness, resilience and financial stability of Islamic banks during the global financial crisis (Caby and Boumediene, 2013), while rare studies measuring EM. Secondly; Grougiou et al (2014) state that their findings cannot be generalized since the sample is country-specific. They recommend that future research could explore the bi-directional CSR-EM relationship using cross-country data provided. Moreover; the potential effects of different cultural, legal, institutional and accounting traditions could be adequately controlled (Kim et al., 2012). The paper is motivated by rare literature that measuring EM for Islamic banks generally and association between EM and CSRD particularly. The majority of literature related to EM focus mainly on developed countries as well as conventional banks (e.g., Katmon \& Farooque, 2015; Gopinath Arun et al., 2015), while just rare studies measuring EM based on Islamic banks' data (e.g., Quttainah et al., 2013). Consequently, we motivated to fills these gaps through measuring EM as well as association between EM and CSRD regarding to Islamic banks. A comparatively contemporary stream of the literature has shown extensive interest in understanding whether corporate commitment to CSR practices plays a role in the quality of financial reporting and vice versa (Scholtens \& Kang, 2013). However, little emphasis has been placed upon investigating this bi-directional relationship in the case of the influential banking sector generally and Islamic banking sector specially. Moreover; the compound annual growth rate for Islamic banking is expected to be higher than $20 \%$ for the next 5 years (Hamdi and Zarai, 2012). Hence, understanding the EM behaviours of Islamic banks is of considerable significance and interest to regulators and investors. We are motivated by 
contains our sample more than one country, while the vast majority of earnings management research has been conducted within a single country using firm level data (Doupnik, 2008).

Our results suggest that Islamic banks engaged in EM practices are not tending to be involved in CSR activities. Furthermore, we show that the reverse association is also not significant, i.e. that the degree of Islamic bank's commitment to CSR is not associated with the quality of financial reporting or EM. We determine that, in the case of the Islamic banking sector across GCC, a nondirectional association develops, as we find that EM is a not significant determinant of CSRD as well as CSRD is a not significant determinant of EM. In light of these results, we contribute to the extant literature by providing insights into the workings of a crucial component of the operation of the GCC economy -Islamic banking sector - which is characterized by a full compliance with sharia; guided by Islamic law; a distinctive tendency to not employ in EM practices and by a high level of participation in CSR activities and disclosure about it. Through deciphering the linking nature of CSRD and EM in the case of the Islamic banking industry, we fill a significant gap in the literature and contribute to the framework for decoding aspects of complex decision-making processes.

Our work is furthermore different in that, while preceding studies use cross-industry (e.g. Chih et al., 2008; Prior et al., 2008), our study focuses on sole sector. Furthermore; Alsaadi et al (2013) uses non-financial sectors data to test the association between EM and CSRD; while our study focused on financial banking sector. In this way, we aim to reduce the interference of any potential noise due to diverse environments and the operationalization of both CSR and EM proxies. Additionally, whilst previous studies have examined either the impact of EM on CSR (Prior et al., 2008) or the impact of CSR on EM (Chih et al., 2008), we provide a more comprehensive understanding of the CSR-EM association by bringing to the fore the element of reverse causality. Moreover; while prior studies have examined the association between EM and CSRD for conventional banks (Grougiou et al., 2014), our research focuses on Islamic banks which have unique characteristics. Previous studies that measuring the association between EM and CSRD are focused on firm characteristics as control variables (e.g., Ibrahima et al., 2015), while our study extends these variables to contain CG factors as board size; board independence and board meetings as well as CG code related to 
SSB as size and independence. We extended work of Quttainah et al (2013) that measuring the determinants of EM for Islamic banks concerned with SSB mechanism to testing the association between EM and CSRD with control SSB variables; BOD and firm characteristics. Whilst previous studies focuses on one country (e.g., Grougiou et al., 2014 study U.S. banks; Ibrahima et al., 2015 study Malaysia banks), whereas we provide a more holistic measuring for this association in six countries which formulated GCC region. Finally; our paper differs from Ibrahima et al (2015) and Grougiou et al (2014) that adopt GRI guidance KLD Research \& Analytics respectively for measuring CSR. Both of them ignore items related to CSR from an Islamic perspective, while our index contains universal as well as Islamic items regarding to CSR activates as Zakat and compliance with sharia. Our findings have a number of important implications for a wider range of stakeholders such as investors, bank managers, market participants and regulators who might consider CSR as a sign of ethical investing and a potential significance of the quality of financial reporting or EM practices. Such groups ought to be very vigilant in depending on CSR information for banking industry analysis, as CSR is documented to be motivated by EM and, at the same time, banks' CSR involvement is reported to have no significant impact on EM. Moreover, through the employment of EM practices, managers may thrive in attaining both optimal levels of profitability and a high CSR record. By doing this, they could enhance their personal reputation capital which allows them to claim improved benefits and rewards, better contracts, and board interlocks -habitually to the loss of their organisation's interests. Regulators should take into consideration the positive impact of EM on CSR and should consider the reformulation of current CSR motivation plans, linking them to frameworks for bank manager advantages and rewards. Bank managers may be motivated to use CSR to cushion the economic consequences of low earnings. Market participants have to take into account that a bank's vigorous participation in CSR might be incentivised by the employment of EM practices used to acquire optimal levels of profitability. They should be mindful that bank managers are more likely to prioritize the CSR agenda and to potentially allocate significant resources to CSR practices; in the meantime attaining preferred levels of profitability could also influence the perceptions of stakeholders who may accept higher investments in CSR. Through EM practices bank managers might thrive in 
accomplishing both optimal levels of profitability and involvement in CSR activities which improve their personal reputation capital and allows them to claim improved advantages, rewards and board interlocks. Finally, in light of our findings, regulators should take into account the positive impact of EM on CSR. They could therefore study the reformulation of existing CSR motivation plans and link them to frameworks for bank manager advantages and rewards. The rest of the paper is organized as follows: in section 2; we review the relevant theoretical framework of the CSR- EM association. In Section 3, we explore CSR as well as EM from an Islamic approach. Section 4 describes the sample selection procedure, measures of EM as well as CSRD and our research models design. In section 5 , we report the empirical findings and detail our Sensitivity analysis. Finally, section 6 present the conclusions drawn from our analysis.

\section{Islamic banking features:}

Maali et al (2006) define IBs as those banks that claim to follow Islamic Sharia in their business transactions. Sharia requires transactions to be lawful (halal) and prohibits transactions involving interest and those involving speculation. The concept of risk sharing is a key feature that distinguished Islamic from conventional banking (Azmat et al., 2015). IBs, therefore, have developed alternatives accordingly which include interest free loans (Qard Hassan), Islamic joint ventures (Musharakah/Mudarabah) and trade or lease based financing (Murabaha/Ijarah/Salam). There are five principles of Islamic banking which is (1) profit and loss sharing (PLS); (2) all transactions have to be backed by a real economic transaction that involves a tangible asset; (3) prohibition of riba (interest) is the most prominent features of Islamic finance; (4) prohibition of gharar (excessive uncertainty) and maysar (excessive risk or gambling) and (5) Prohibition on financing for illicit sectors (e.g., alcoholic; pork products, tobacco; gambling and drugs) (Khediri et al., 2015). To make sure that the religious expectations of those who deal with IBs have been met, IBs appoint a religious auditor; Sharia Committee or sharia supervisory board (SSB) (Daoud, 1996). The members of this Committee shall have the necessary qualification and knowledge on Islamic jurisprudence and Islamic transaction law (Fiqh al-Mu'amalat). The responsibilities of SSB include ex ante and ex post auditing of transactions, the calculation and payment of Zakah, and advising the bank on its accounting polices (Karim, 1990). 


\section{The GCC Islamic banking industry:}

Islamic banking and finance has grown exponentially over the last 20 years. Actually, there are more than 300 Islamic financial institutions (IFIs) worldwide including banks, mutual funds and insurance firms (Khediri et al., 2015). By the end of 2014, the total assets of the Islamic financial industry is estimated to surpass $\$ 2$ trillion and, with this estimate, the compounded average growth rate of the total Islamic assets would be $17.3 \%$ over 2010-2014 and will grow by an average of $19.7 \%$ a year to 2018 (Economist, 2015). One important group of banking services that have experienced rapid growth in GCC countries is the Islamic financial services (Srairi, 2010). Sharia-compliant assets represent a significant portion of total banking assets of the GCC. GCC region accounted for $38.2 \%$ of global Islamic banking assets. GCC Islamic banking assets reached \$564 billion at 2014 (IFSB, 2015). Banks in the GCC account for nearly one-third of all Islamic banking assets worldwide (Ernst \& Young, 2015). These are mainly concentrated in Bahrain, Kuwait and the UAE. During the last 10 years, the concept of Islamic banking has likewise developed to cover activities of other types of financial institutions including insurance, investment and fund management companies. Moreover, to take advantage of Islamic financial instruments, many conventional banks in GCC countries have added Islamic banking services to their regular banking operations. Cooperation Council for the Arab States of the Gulf region (Gulf Cooperation Countries (GCC)) has a rich history of banking sector, going back to 1918 when the British first opened a bank in Bahrain (Olson and Zoubi, 2008). Islamic banks operate in over 60 countries, and most of them are in the GCC and Asia (Quttainah et al., 2013). Thus, GCC is represent one of the main Islamic hub centre for Islamic banking industry in the world. Therefore, the current paper focuses on the GCC countries. This region is worth studying for several reasons: the GCC region has one of the world's largest Islamic banking markets (Al-Hassan et al., 2010); and the financial sector in the GCC is relatively developed compared to other countries in the Middle East (Maghyereh and Awartani, 2014). Banking is one of the largest sectors in GCC economies and there are more bank stocks traded in GCC stock markets than stocks of any other industry (Olson and Zoubi, 2008). Today, the GCC countries are widely believed to have the most developed Islamic financial system in the world containing a large Islamic banking sector, a well-developed Islamic interbank 
money market, a growing Islamic securities market (Sukuk) and a sophisticated Islamic insurance market (Takaful) and operating side-by-side with a conventional banking system (Grassa and Gazdar, 2014).

\section{Theoretical framework of the CSR- EM association:}

This section reviews the theoretical frameworks that can be drawn upon to comprehend the inter-association between CSR and EM. Exploring this valuable insights association are provided by various perspectives such as stakeholder; legitimacy and signalling theories. As demonstrated by a number of previous studies Stakeholder theory have been one of the utilised theories, which sheds light on the EM-CSR association. Such a theory is concerned with how top board management teams manage their stakeholders (Mitchell et al., 1997). For example, top board management teams endeavour to serve multiple stakeholder objectives, which result in a widening information asymmetry between managers and stakeholders. Thus, shareholders do not have adequate resources or access to information to observe directors' actions (Richardson, 2000). In succession, this information asymmetry prompts the rise of EM practices (Jensen, 2010). Henceforth, stakeholder theory offers meaningful insights into managerial behaviours by proposing that bank directors who participate in CSR activities to negotiate diverse stakeholder interests are also involved in EM practices. Consequently; According to the stakeholder perspective, CSR has a positive impact on EM (Grougiou et al., 2014).

Legitimacy theory is one of the theories, which have been employed to explain this phenomenon in prior investigations. At the heart of this theory is the concept of organisational legitimacy, which is understood as a generalised perception that the activities of an organisation should be within the prevailing system of values and beliefs (Suchman, 1995). Such an organisation would enjoy legitimacy as far as they exhibit that their activities are consistent with broad social acceptations (Castello \& Lozano, 2011). Further, CSR activities are used as an effective tactics deployed by top management team directors to confer legitimacy upon their organisations (Hahn \& Kuhnen, 2013). Also organisations employ CSR practices to manage or manipulate the informational needs of the different influential stakeholder groups in society in order to win their support, which is in this case vital for survival (Gray et al., 1995). Scholtens and Kang (2013) claim that top team 
directors pursue their own interests by divulging profits in financial statements, which do not demonstrate a precise picture of the true economic position of the organisation. Thus, EM activities are conceptualized as opportunistic practices through which directors inflate earnings to meet budget goals as a means of increasing their own compensation (Hong \& Andersen, 2011). Therefore, legitimacy theory sheds light upon managerial behaviours and incentives by proposing that bank directors who are vigorously involved in EM activities, with a view to show enhanced representations of their firm's profitability, preemptively resort to CSR practices (Mahjoub \& Khamoussi, 2013) to avoid attention from questionable financial reporting. EM has a positive effect on CSR in light of the legitimacy theory

Also, the Signalling theory provides an alternative understanding of the relationship between CSR-EM (Conelly et al., 2011). Which is that organisational legitimacy may be achieved by signalling organisation's unobserved qualities to third parties. Also, owning to the imperfect information, market participants (receivers) are not always mindful of important internal information concerning corporate practices. Thus, managers (signallers) are motivated to convey signals which are relevant to the adherence of CSR norms, in order to confer legitimacy upon their organisation. According to this perception, certain banks energetically capitalise on CSR practices to project their superior type (Clarkson et al., 2008) in terms of social sensitivity criteria. Such banks will obtain an advantageous position by showing their distinctive CSR accomplishments, which challenges the rest of the industry to duplicate. Thereafter, the signalling theory proposes that a bank's engagement in CSR practices is irrelevant to the advancement or degradation of the organisation's financial reporting quality. Therefore, the intensity of CSR activities/engagement has no influence on EM. Thus, based on the signalling theory, CSR is seen as disassociated from EM (Grougiou et al., 2014). Based on the above discussion, this study will utilise the signalling theory due to its relevance to this study's main argument which is the employment of CSR reporting and earnings management manipulation. Thus, we adopt this perspective based on ethical and moral background for institutions that rise flag of Islam and guided by sharia. It involves in CSR activities to achieve its accountability towards Allah (God) then all stakeholders not to manipulate its earnings. Consequently, we expect insignificant bidirectional association between EM and CSRD for both models. 


\section{CSR and EM from an Islamic perspective:}

\subsection{Earning Management:}

In terms of the impact of religion on mitigating EM, recent studies find a positive influence of religious ethical norms on earning quality. Dyreng et al (2012) investigate whether firms with more religious influence are less likely to engage in aggressive financial reporting than firms with less religious influence. They find that firms that are religion-influenced are less involved in aggressive financial reporting and have higher accrual quality. McGuire et al (2012) argue that religion reduce unethical practices in business organisation. They find that firms that in religious area experience lower incidences of financial reporting irregularities.

Islam has a similar and unique value to other religions in that its principles and norms guide all aspects of human life, including business activities (Alsaadi et al., 2013). IBs are established based on the article of incorporation that states that operation should comply with Sharia. Sharia entails the notion of protecting the interest and rights of all stakeholders within the Sharia rules (Hasan, 2008). Islamic philosophy represents a religious-based system of business ethics which characterized by the ethical and moral norm that is socially committed. Hence, Sharia plays an important role in shaping the ethical behaviours of Islamic banks managers. The religiosity literature implies that religiosity is positively associated with risk aversion and negatively associated with unethical behaviour (Dyreng et al., 2012). Thus, we expect that IBs are less likely to engage in EM due to the moral and ethical values that Sharia stresses upon. Transparency is one of ethical responsibilities according to the Islamic rules, and Sharia principles assert that business activities should be carried out in a transparent manner that every aspect of these activities is clarified to various parties (Ali and Al-Owaihan, 2008). It has been argued that disclosing more information about a firm's activities leads to mitigate information asymmetry and enhance a firm's transparency as well as reducing incentive of involving on EM manipulation and enable investors to detect such unethical behaviour ( $\mathrm{Jo}$ and Kim, 2008). In Islam, exploiting the contracting agreements by managers are prohibited as well as managing trust given to them by using unethical way such as EM. Abdul-Rahman et al (2012) conclude that religious ethical values reduce aggressive reporting practices and managerial opportunism. 


\subsection{Corporate social responsibility:}

For Thakur (1996) religion can play a significant part in evolving the cause of social accountability through its emphasis on morality and spiritual visions necessary for attaining social justice in society. Islam make claims that the main purpose of their message and teaching is to advance social justice in societies (ElGamal, 2006). In the Islamic context, the social responsibilities of individuals which are derived from the Qur'an and from Prophet Mohammed's deeds, teachings and sayings (Sunnah) also apply to companies. It is legitimate for a business to aim to realise profits, but this goal should be pursued in accordance to the Sharia (Mallin et al, 2014). Since Sharia defines the norms of human conduct, and how business has to deal with its external environment, businesses claiming to comply with Sharia should be clearer about their roles in society (Maali et al., 2006). Darus et al (2013) contends that the practices and policies of CSR of Islamic institutions as Islamic banks should be prioritised in accordance to their importance and urgency from the perspective of Sharia. The prioritisation of CSR will relate to the objective of Sharia and to ensure that the society's interests are preserved, which is also consistent with the motivation for sustainability practices.

IBs refer to a system of banking that is concurrent with the values of Islamic jurisprudences (Sharia). Sharia is concerned with encouraging justice and welfare in the society and seeking God's blessings, with the ultimate aim of attaining success in this world and the hereafter (Hassan and Harahap, 2010). The payment of parts of bank's profits to benefit the society is a representation of one of the main unique characteristics of IBs. IBs market themselves knowingly on ethical and social grounds (Visser, 2009). According to Islamic values, business transactions can never be separated from the moral objectives of the society (Usmani, 2002). Therefore, IBs are more predicted to be more receptive to the diverse requirements of all stakeholders groups. Moreover, IBs are more likely to enact the role of reallocating profits acquired (for instance via the Musharaka programme; profit and loss sharing) to carefully chosen investments, which contribute to the overall enhancement and well-being of the wider society (Farook, 2008; Mallin et al., 2014). Additionally, IBs should endeavour to attain equilibrium between offering adequate revenues to their investors and depositors, while at the same time not disregarding their social responsibilities and obligations towards their divers stakeholder groups (Ahmad, 2000). It has also been established 
that IBs have 'a social face' (Mashhour, 1996). This is officially recognised by numerous banks 'social activates are emphasized in Islamic banks' articles of association among their objectives and functions' (El-Ashker, 1987, p. 45). Kim et al., (2012) provide evidence that CSR practices are negatively related to EM. The moral value in CSR drives management not to manipulate their financial information.

Based on the above discussion; we argue that IBs face greater demands of conducting ethical and social activities as well as providing more transparent and reliable financial reporting as a result of their Sharia status. The Islamic moral codes is expected to mitigate unethical behaviour as well as reduce the intention of mangers to engage in EM and provide less reliable information, which in turn violate the concept of justice. This enhances IBs to maintain higher standards of accountability in their reporting practices. The above argument provides evidence that engaging in CSR is driven more by moral imperative rather than opportunistic behaviour and EM is mitigated as a consequence of Sharia principles. Therefore, this study predicts that IBs are perceived to have embraced the Islamic values would be more concerned with their social responsibility and would be less likely to be involved in EM.

\section{Research design:}

There are 40 Islamic banks across the Gulf Cooperation Council (GCC) (Qatar, KSA, UAE, Oman, Bahrain and Kuwait) based on Islamic Financial Services Board (IFSB) report (IFSB, 2015). Our sample is balanced panel data of 29 IBs $(72.5 \%)$ from six GCC countries: 13 banks in Bahrain, 2 banks in Kuwait, 2 banks in Oman, 4 banks in Qatar, 4 banks in Saudi Arabia, and 4 banks in United Arab Emirates during the five-year period 20122016. The selection of banks in the sample is based on the availability of data for the required period. Following previous studies (e.g., Anandarajan et al., 2007; Leventis et al., 2001), we exclude banks with incomplete data from the sampling frame; Islamic windows and conventional banks. Altogether the final data set comprises 145 observations. Financial data and EM score for each bank are obtained mainly from data stream, bank scope and Blomberg database. The sources of extent of CSRD data for each bank are obtained from the annual reports and websites. As part of the documentary analysis we have undertaken a content analysis of all annual reports of IBs. We have considered 
published annual reports as this has been the most consistent and regular medium for the bank to communicate with its stakeholders. To point out the importance of annual reports Gray et al (1995) suggested that they are published consistently and help to construct an external image of corporation.

\subsection{Measuring earnings management:}

Healy and Wahlen (1999) defined EM as the alteration of a corporation's financial reports by insiders as board and managers to mislead stakeholders or to influence contractual outcomes that are dependent on numbers in the financial reports. Measuring the extent of EM has presented challenges, and researchers have devised various methods (see Dechow et al., 2010, for details). In this study, we adopt the method developed by Leuz et al. (2003), which were based on previous work by Dechow et al., (1995), Dechow and Skinner (2000). This model also adopted by several literatures (e.g., Wang and Campbell, 2012). We first introduce accruals and cash flow. Cash flow from operations is computed indirectly by subtracting the accrual component from earnings because direct information on firms' cash flows is not widely available in many countries. Following Dechow et al. (1995), we compute the accrual component of EM as

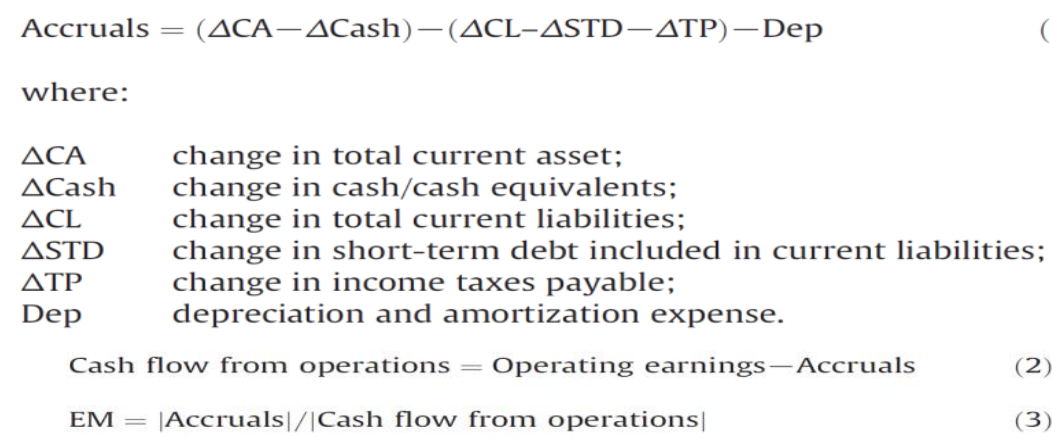

6.2 Measuring corporate social responsibility:

In this study related to CSRD, to construct an overall measure of IBs' commitment to CSR, we have used a disclosure index which consists of a comprehensive list of 149 disclosure items across 16 categories. This index is adopted from Belal et al 2014. The index contains Universal items that are shared with internationally recognized initiatives as Global Reporting Initiative (GRI) guidelines on financial services as Board of Directors; management; charity; sponsorships; complaints; ethics; employees; environment and community involvement in 
additional to particular or Islamic items that are required for Sharia-compliance as SSB; Zakat; Qard Hassan; Sharia awareness and Islamic commitments. We consider these qualitative issue areas to be more relevant to IBs. Consider mixed variables (Universal and Islamic) is consistent with Belal et al 2014. The content analysis instrument used in this case further extends the instruments used in previous research (e.g., Haniffa \& Hudaib, 2007; Maali et al., 2006). For each item disclosed in a year we used a score of 1 or 0 (if not disclosed). We have used an un-weighted indexing procedure to avoid possible bias in scoring. This is consistent with previous studies (e.g., Ahmed \& Nicholls, 1994; Cooke, 1989). For each year an index was calculated by dividing the number of items disclosed with total number of items to be disclosed. We interpret a higher CSR score as an indication of a bank's greater commitment to CSR practices.

\subsection{Empirical model:}

To test the association between CSR and EM, we estimate a linear simultaneous equations system of two cross-sectional models since Labelle et al (2010) suggest that CSR and EM might be endogenously determined. Therefore, to put both EM score and the factors related to CSRD on the right-hand side of an equation having CSR as its dependent variable would lead to biased and inconsistent OLS estimates (Gujarati, 1995). Actually, contemporary CSR studies highlight the significance of controlling for endogeneity problems (Garcia-Castro et al., 2010; Hillman \& Keim, 2001). Gujarati (1995) recommend addressing a possible endogeneity problem by estimating a 2SLS regression and this method has been used in several studies (e.g., OwusuAnsah et al., 2010).

In the first stage, the endogenous variable EM is regressed against exogenous variables, whose selection is dictated by prior studies. Following previous studies (Kanagaretnam et al., 2010; Quttainah et al., 2013), we include several bank characteristics as well as CG variables that could affect bank EM as well as CSRD in the empirical analysis. Thus, we include in Equation (4): corporate social responsibility disclosure (CSRD) and profitability (ROA) (Kothari et al., 2005); bank size (SIZE) (Cornett et al., 2009); leverage (LEV) (Ali and Zhang, 2015; Sun et al., 2010); board size (Ferraz et al., 2011); board independence, board meetings (Chi et al., 2015; Gonza'lez and Garcı'a-Meca, 2014); SSB size (Quttainah et al., 2013) and audit committee presence and audit 
committee size (Chen and Zhang, 2014). Grougiou et al (2014); Scholtens (2009) suggest that risk should be controlled for in any model that tests EM-CSR association. Therefore, we control for capital risk by including CAP as Cornett et al (2009). Finally, we included YEA and COU in the model to control year and country affects which consistent with Katmon and Al Farooque (2015). We specify the functional form of first-stage regression as:

$$
\begin{aligned}
\text { EM }_{i t}=\beta 0 & +\beta 1 \text { CSRD }_{i t}+\beta 2 \text { ROA }_{i t}+\beta 3 \text { LEV }_{i t} \\
& +\beta 4 \text { SIZE }_{i t}+\beta 5 \text { B.SIZE }_{i t} \\
& +\beta 6 S S B . S I Z E_{i t}+\beta 7 B . I N D E P_{i t} \\
& +\beta 8 B . M E E T_{i t}+\beta 9 A C . E_{i t} \\
& +\beta 10 A C . S I Z E_{i t} \\
& +\beta 11 C A P_{i t}+\beta 12 C O N . D U M_{i t} \\
& +\beta 13 \text { YEA.DUM } M_{i t}+\varepsilon_{i t}
\end{aligned}
$$

Where $\mathbf{E M}=$ earning management measure; $\mathrm{CSRD}=$ corporate social responsibility disclosure score based on CSR index; B.IND=Board independence (ratio of the number of non-executive directors to tot al number of directors); B.SIZE = total number board members; B.MEET=number of BOD meeting within the year; $\mathrm{AC}=$ dummy variable 1 if there is audit Committee inside the Islamic banks or 0 otherwise; AC.SIZE=total number of audit committee; SBB.SIZE=total number of SSBM on the board; SIZE= natural logarithm of total assets; $\mathrm{ROA}=$ profitability ratio based on return on assets; $L E V=$ leverage ratio based on total liabilities for total assets; $C A P=$ ratio of actual regulatory capital (Tier 1 capital) to the minimum required regulatory capital; CON.DUM=Country dummies and YEA.DUM=Year dummies.

In the second stage, CSR is regressed on the fitted values of EM, which is derived from the first-stage regression and the actual values of the exogenous variables, whose selection is based on previous studies while taking into consideration the particularities of banks. Specifically, we comprise in Equation (5): SIZE (Andrikopoulos et al., 2014; Mallin and Michelon, 2011); SSB size and SSB cross membership (CM) (Farook et al., 2011); SSB reputation (R) (Abdul Rahman and Bukair, 2013); Leverage (LEV) (Drobetz et al., 2014; Guidry and Patten, 2012); ROA (Faraga et al., 2014; Mallin and Michelon, 2011); Board independence, board meetings and board size (Jizi et al., 2014); Capital risk (CAP) (Prior et al., 2008); Age (Hossain and Hammami, 2009) and accounting standard (Evans et al., 2015; 
Barth et al., 2012) ${ }^{1}$. Thus, we estimate the following structural equation:

$$
\begin{aligned}
\text {CSRD }_{i t}=\beta 0 & +\beta 1 E M_{i t}+\beta 2 \text { ROA }_{i t}+\beta 3 \mathrm{LEV}_{i t} \\
& +\beta 4 S I Z E_{i t}+\beta 5 S S B . C M_{i t}+\beta 6 \text { B.SIZE } \\
& +\beta 7 S S B . S I Z E_{i t}+\beta 8 S S B . R_{i t} \\
& +\beta 9 B . I N D E P_{i t}+\beta 10 B . M E E T_{i t}+\beta 11 \text { CAP }_{i t} \\
& ++\beta 12 S T A N D_{i t}+\beta 13 A G E_{i t} \\
& +\beta 14 C O N . D U M_{i t}+\beta 15 Y E A . D U M_{i t} \\
& +\varepsilon_{i t}(5)
\end{aligned}
$$

Where all variables are defined as per Equation (4) except for those first introduced in Equation (5), which are defined as: SSB.CM= dummy variable 1 if SSB member with a cross membership in more than one Islamic bank or 0 otherwise; SSB.R= dummy variable 1 if the SSB members are has membership in a credible Islamic institutions as AAOIFI or 0 otherwise; STAND=dummy variable 1 if the banks adopt AAOIFI/other Islamic standards or 0 otherwise; $\mathrm{AGE}=$ age of the bank.

Table 1 presents the summary statistics of the variables used in our tests related to our two models. Table 2 reports the correlation coefficients between the dependent and independent variables. Observations for all variables in the correlation matrix show that most of the correlation coefficients are below $80 \%$. A correlation coefficient of more than $80 \%$ indicates serious multicollinearity (Gujarati, 1995).

(Insert here table 2)

\section{Empirical findings:}

The two models presented in table 4 are well identified; the $R$ squared in first and second model are $59.8 \%$ and $63.7 \%$ respectively. The $F$ statistics are highly significant and reject the null that the coefficients are insignificantly different from zero. A variance inflation factor (VIF) check of our two models shows maximum VIF is 5.854 for CAP, which is below the 10-point benchmark (Hair et al., 2006). As such, it can be concluded that the multicollinearity is not detrimental to the results of the multivariate analysis. The Ramsey RESET test for omitted variables and model mis-specification fails to reject the null that the model is not mis-specified and concludes that there is no omitted variables bias and our models are well specified.

\footnotetext{
1 Audit firm size (Grougion et al., 2014; Kim et al., 2012) and auditor change (Grongion et al., 2014; De Fond \& Subramanyam, 1996) variables has been excluded since there were no change in data over the selected five period.
} 
Our results are not matching with the previous literature that finds a positive association between EM and CSR (e.g., Hong and Andersen, 2011), and other literature that finds a negative association (e.g., Chih et al., 2008). However, this finding is equivalent with Ibrahima et al (2015) that find insignificant association between the two variables. For first model (Equation, 4), where EM is the dependent variable, the coefficient of CSRD is negative and not statistically significant. This proposes that CSR activities do not clarify why GCC IBs indulge in EM practices. This result is consistent with Grougiou et al (2014) regarding to previous research on financial corporations, whereas our finding does not matching with (Labelle et al., 2010) concerning with nonfinancial corporations. For the control variables, ROA and B.MEET only are statistically significant. $R O A$ is significant at the $1 \%$ level with a positive coefficient, proposing an inter-correlation between ROA and EM practices (It is consistent with Ali and Zhang, 2015). Kothari et al (2005) argue that there is spurious indication of EM being high in banks with high financial performance. We found that board meeting is significant at the 5\% level, with an unexpected negative sign. Our result is consistent with Conger et al (1998). Xie et al (2003) argue that board meeting frequency is associated with reduced levels of EM and an expectation that more active board will prove more effective monitors. They point out that boards that spend more hours on meeting are able to exercise greater monitoring functions, so they are more likely to be able to curb EM. Chen et al (2006) disclose that fraud or EM level is less likely to occur in corporations with a greater number of board meetings, because they have sufficient time to solve a bank's financial problems and to exercise their duty and accountability in line with shareholder interests, and then improve a firm's performance.

For second model (Equation, 5), where CSRD serves as the dependent variable, the coefficient of EM is positive and also statistically insignificant as reported in first model. This proposes that IBs that engage in EM practices are not necessarily actively involved in CSR activities. This outcome is matching with Ibrahima et al (2015) related to IBs, while it is against Grougiou et al (2014) concerned with conventional banks. Related to the control variables, size; standards; age and board meetings are statistically positively significant with CSRD. SIZE is significant at the $1 \%$ level, proposing that large IBs are more likely to engage in CSR activities. This result is consistent with Drobetz et al 
(2014). The result shows that age is significant at the $10 \%$ level which consistent with previous works (Mallin et al., 2014; Roberts, 1992). We argue that the older the bank the more involvement there will be in CSR activities which have a positive impact on its reputation. For accounting standards, it is significant at the $1 \%$ level, proposing that IBs that adopting AAOIFI are more likely to engage in CSR activities as well as disclose more information about these activities. This outcome is matching with Evans et al., 2015. Finally; our result is matching with (Arora and Dharwadkar, 2011; Li et al., 2008) that find a significant association between CSRD and board meetings at the 5\% level.

(Insert here table 3)

\section{Sensitivity analysis:}

We check the robustness of our findings by performing several sensitivity tests. First; we added other country variable to measuring its impacts on the association between EM and CSRD which is Governance Index which taken from the research project "Worldwide Governance Indicators" (WGI) proposed by Kaufmann et al. (2010) to control for institutional differences among different countries. We integrate this index using three main indicators that previous literature has shown as very important factors in measuring the way in which the governability of a country helps to reduce or increase opportunistic behaviour in firms related to EM as well as CSRD: Government Effectiveness; Rule of Law and Control of Corruption (Gonza'lez and Garci'a-Meca, 2014; Galang, 2011). This would require us to run a third equation where contains WGI variables instead of dummy variable for country. Therefore, we exclude the CON.DUM or Country dummies variable from our system of equations and re-estimate the 2SLS system. The findings are similar to those reported earlier which is un-significant association between CSRD and EM.

Secondly, previous research shows that EM (Cornett et al., 2009) and CSRD (Andrikopoulos et al., 2014) models are sensitive to corporation size, thus we assess the effect of size on our results. As recommended by Chow (1960), we perform an F-test to define whether the estimates of the full sample model are consistent through the lower and upper shares of our sample. Hence, we divide our full sample of Islamic banks into lower and upper shares based on the median of their total assets. The untabulated findings of the Chow test specify that there is no statistical 
difference in the regression estimates for SIZE between the lower (small bank) and upper (large bank) segments of our sample $\left(X^{2}\right.$ statistic $=0.05$, two-sided $p$-value $=0.8432$ ). Thus, SIZE has no disproportionate effect on our results.

Thirdly, while the pair wise correlation coefficients reported in Table 1 do not specify any multicollinearity problems in our data, the presence of a definite degree of collinearity is still potential. This is because one independent variable may be an approximate linear function of a set of several other independent variables and, also, simultaneous estimators break down in the face of multicollinearity (Farley \& Leavitt, 1968). Consequently, we compute a post-estimation variance-covariance of the estimators (VCE) of the variables in Eq. (5). Similar to the findings of the Pearson product-moment correlation procedure reported in Table 1 , the VCE suggests that the degree of multicollinearity is not severe.

\section{Conclusions remark:}

IBs and CSR are both areas which have seen significant growth in recent years with rare studies that measuring EM based on Islamic banking sector data. In an attempt to fill the gap in the literature concerning with the association between EM and CSRD, we investigate this relationship using a sample of 29 IBs across GCC during the five-year period 2012-2016. Our analysis suggests that there is insignificant association between EM and CSR, i.e. that IBs board who (if) manipulate earnings are not tend to involve in CSR activities. Our findings demonstrate that accounting earnings are not associated with intensive investment in CSR activities. Furthermore, our findings suggest that the extent of IBs' engagement in CSR activities is not influential in deter-mining a bank's indulgence in EM practices. By combining legitimacy and signalling theories, we argue that, banks resort to CSR practices to signal internal qualities and to build a distinct socially responsible organizational profile. Incentivized by building a superior image and attaining prominence, banks organize CSR strategies to differentiate themselves from other institutions in the industry, without such tactics having any impact on EM. Moreover, our analysis shows that banks with greater capacities in terms of ROA and board meetings are in a more privileged position to maintain and re-establish superiority. Overall, our study indicates that the CSR-EM relationship is bi- 
directional. This is demonstrated by our results which show that, a high engagement in EM does kink with engagement in CSR, involvement in CSR does not determine EM practices. Therefore, we do not find evidence about the association between EM and CSRD regarding to Islamic banking sector in GCC. The insignificant findings between EM and CSR prove that Islamic banks that are offering Islamic services and represented Islamic philosophy for conducting business and are engaging in sustainability initiatives are not doing so to cover their engagement in EM practices. Thus, it can be concluded that the acts of IBs are consistent with the objective of Sharia which is aims to serving the society as a real accountability towards Allah and all stakeholders. It also guided by prohibited any misleading for any interested parties by any method as manipulation of earning. This conclusion is supported by Quttainah et al (2013) that argue that IBs are less likely to conduct EM comparing with other rivals particularly non-Islamic or conventional banks.

The result disagree with the argument of Kim et al (2012) who claim that CSR may be adopted by corporations in order to create an impression of transparency among the stakeholders and legitimise their activities and gain stakeholder sustenance, when in fact they are engaging in accounting-based and real EM. This can be justified based on ethical; moral and religious background and basics for IBs as well as their managers. Also; Ethical theory view CSR as an ethical imperative or obligation and state that companies must accept this view and treat social responsibility above any other concern. According to this perspective, engagement in CSR by Islamic banks is significant and must be driven by moral obligation rather than used as a tool to manipulate their earnings or hide managers' opportunistic behaviour (Alsaadi et al., 2013). Thus, if the moral imperative is the driver behind CSR, firms as Islamic banks are expected to be more likely to provide high-quality earnings disclosure and limit EM, thereby enhancing the transparency of financial reporting. Therefore, in terms of conducting business activities according to Islamic principles, there is no a gap between what have been highlighted in theoretical framework or signalling theory and practices. By other words; our result supported the main basic for signalling theory that argues that CSR is seen as disassociated with EM as well as the Reverse association.

We note that our findings should be interpreted in the light of several limitations which, however, may motivate future research. 
First, our sample might not be so large as to represent the whole Islamic banks population. For this reason, future research could measure the bi-directional CSR-EM relationship using the all IBs around the world which are approximately 160 across 30 countries. Secondly; because the main uniqueness of IBs is full compliance with sharia, we expect that future research will look into sharia disclosure quality issues and its association with EM practices. The analysis shows significant impacts of accounting standards on EM practices. Thus, we expect further research consider for what extent as well as how adopting AAOIFI has effects on reducing the level of EM for IBs by focusing on the EM practices before and after adopting these standards. Our sample period is limited to the five years between 2010 and 2014. Upcoming research may advance existing understandings through extending the sample period chronologically by using panel data analysis which allow for an investigation of the long-term association between EM and CSRD in Islamic banking sector.

\section{References:}

Abdul Rahman, A., \& Bukair, A. (2013). The Influence of the Sharia Supervision Board on Corporate Social

Responsibility Disclosure by Islamic Banks of Gulf CoOperation Council Countries. Asian Journal of Business and Accounting, 6 (2), 65-105

Abdul-Rahman, R., Rahman, A., and Courtenay, S. (2012). Religious ethical values and Accounting Conservatism:

Some evidence from Malaysia, Working Paper, JCAE Symposium, Kulala Lumpur, Malaysia

Ahmed, S., Islam, M. \& Hasan, I. (2012). Corporate Social Responsibility and Financial Performance Linkage-

Evidence from the Banking Sector of Bangladesh. Journal Organizational Management, 1(1), 14-21

Ahmad, K. (2000). Islamic finance and banking: The challenges and prospects. Review of Islamic Economics, 9, 57-82 
Ahmed, K., \& Nicholls, D. (1994). The Impact of Non-Financial Company Characteristics on Mandatory

Disclosure Compliance in Developing Countries: The Case of Bangladesh. The International Journal of Accounting, 29, 6277

Ali, A., \& Zhang, W. (2015). CEO tenure and earnings management. Journal of Accounting and Economics, 59, 60-79

Ali, A., \& Al-Owaihan, A. (2008). Islamic work ethic: A critical review. Cross Cultural Management: An International Journal, 15 (1), 5-19

Al-Hassan, A., Khamis, M., \& Oulidi, N. (2010). The GCC Banking Sector: Topography an Analysis. IMF Working

Paper, WP/10/87

Alsaadi, A., Jaafar, A., \& Ebrahim, S. (2013). Corporate Social Responsibility, Sharia-Compliant and Earning

Management. Seventh Asia Pacific Interdisciplinary

Research in Accounting Conference, Kobe 26-28 July

Anandarajan, A., Hasan, I., \& McCarthy, C. (2007). Use of loan loss provisions for Capital, Earning

Management and signalling by Australian banks.

Accounting \& finance, 47 (3), 357-379

Andrikopoulos, A., Samitas, A., \& Bekiaris, M. (2014). Corporate social responsibility reporting in Financial

Institutions: Evidence from Euronext. Research in International Business and Finance, 32, 27-35

Arora' P., \& Dharwadkar, R. (2014). Corporate Governance and Corporate Social Responsibility (CSR): The

Moderating Roles of Attainment Discrepancy and Organization Slack. Corporate Governance: An International Review, 19 (2), 136-152

Azmat, S., Skully, M., \& Brown, K. (2015). Can Islamic banking ever become Islamic? Pac Basin Finance journal, 34,

246-265 
Barth, M., Landsman, W., Lang, M., \& Williams, C. (2012). Are IFRS-based and U.S. GAAP based Accounting

Amounts comparable? Journal of Accounting and Economics, $54(1), 68-93$

Beatty, A., Keand, B., \& Petroni, K. (2002). Earnings management to avoid earning declines across publicly and

Privately held banks. The accounting review, 77 (3), 547-570

Beck, T., Demirguc-Kunt, A., \& Merrouche, O. (2013). Islamic vs. conventional banking: Business Model Efficiency

and stability. J. Bank. Financ.

http://dx.doi.org/10.1016/j.jbankfin.2012.09.016

Belanes, A., \& Hassiki, S. (2012). Efficiency in Islamic and conventional banks: a comparative analysis in the MENA

Region. Bank. Mark. Invest. 120, 36-49

Belal, A., Abdelsalam, O., and Nizamee, S. (2014). Ethical Reporting in Islami Bank Bangladesh Limited (1983-

2010). Journal of Business Ethics, DOI 10.1007/s10551-014$2133-8$

Caby, J., \& Boumediene, A. (2013). The financial volatility of Islamic banks during the subprime crisis. Bank, Mark.

Invest. 126, 30-39

Castello, I., \& Lozano, J. (2011). Searching for new forms of legitima cy through corporate responsibility Rhetoric.

Journal of business ethics, 100 (1), 11-29

Chen, G., Firth, M., Gao, D., \& Rui, O. (2006). Ownership structure, corporate Governance and fraud: Evidence

From China. Journal of Corporate Finance, 12, 424-448

Chen, J., \& Zhang, H. (2014). The Impact of the Corporate Governance Code on Earnings Management -

Evidence from Chinese Listed Companies. European Financial Management, 20 (3), 596-632 
Chen, Y., \& Hasan, I. (2006). The Transparency of the Banking System and the Efficiency of Information-based

Bank Runs. Journal of Financial Intermediation, 15 (3) 307331

Chi, C., Hung, K., Cheng, H., \& Lieu, P. (2015). Family firms and earnings management In Taiwan: Influence of corporate governance. International Review of Economics and Finance, 36, 88-98

Chih, H., Shen, C., \& Kang, F. (2008). Corporate social responsibility, investor protection and earning

Management: Some international evidence. Journal of Busine ss Ethics, 79 (1/2), 179-198

Chow, G. (1960). Tests of equality between sets of coefficients in two linear Regressions. Econometrica, 28 (3) 591-

605

Clarkson, P., Li, Y., Richardson, G., \& Vasvari, F. (2008). Revisiting the relation between environmental performance and environmental disclosure: An empirical analy sis. Accounting, Organizations and Society, 33

(4), 303-327

Conelly, B., Certo, S., Ireland, R., \& Reutzel, C. (2011). Signalling th eory: A review and assessment

Journal of Management, 37(1), 39-67

Conger, J., Finegold, D., \& Lawler, E. (1998).Appraising boardroom performance. Harvard Business Reviews, 76 (1), 136-148

Cooke, E. (1989). Disclosure in the Corporate Annual Reports of Swedish Companies. Accounting and Business Research, 19 (74), 113-24

Cornett, M., McNutt, J., \& Tehranian, H. (2009). Corporate governanc e and earnings management at Large US bank

Holding companies. Journal of Corporate Finance, 15(4), 412 $-430$ 
Daoud, H. (1996). Sharia Control in Islamic Banks. The International Institute of Islamic Thought

Darus, F., Yusoff, H., AbangNaim, D., Mohamed Zain, M., Amran, A., Fauzi, H., Purwanto, Y. (2013).

Islamic Corporate Social Responsibilities (i-CSR) Framework for Islamic Banks: Application of Maqasid al-Syariah and Maslahah Principles. Issues in Social and Environmental Accounting, 7 (2), 102-112

Dechow, P., Ge, W., \& Schrand, C. (2010). Understanding earnings q uality: A review of the proxies, their

Determinants and their consequences. Journal of Accounting a nd Economics, 50 (2/3), 344-401

Dechow, P. M., \& Skinner, D. J. (2000). Earnings management: Reco nciling the view of accounting

Academics, practitioners and regulators.

Accounting Horizons, 14 (2), 235-250

Dechow, P., Sloan, R., \& Sweeney, A. (1995). Detecting Earnings Management. The Accounting Review, 70(2), pp: 193225

DeFond, M., \& Subramanyam, K. (1996). Auditor changes and discretionary accruals. Journal of Accounting and Economics, 25(1), 35-68.

Doupnik, T. (2008). Influence of Culture on Earnings Management: A Note. ABACUS, 44 (3), doi: $10.1111 / \mathrm{j} .1467-6281.2008 .00265 . \mathrm{x}$

Drobetz, W., Merikas, A., Merika, A, \& Tsionas, M. (2014). Corporate social Responsibility Disclosure: The case of International shipping. Transportation Research Part E, 71, $18-44$

Dyreng, S., Mayew, W., \& Williams, C. (2012). Religious social norms and corporate Financial Reporting. Journal of

Business Finance \& Accounting, 39 (7-8), 845-875 
Economist (2015). Available online on, http://www.economist.com the last access was 30-12-2015

El-Ashker, A. (1987). The Islamic Business Enterprise, London: Croom Helm

El-Gamal, A. (2006). Islamic Finance: Law, Economics and Practice, Cambridge University Press

Evans, M., Houston, R., Peters, M., \& Pratt, J. (2015). Reporting Regulatory Environments and Earnings

Management: U.S. and Non-U.S Firms Using U.S. GAAP or IFRS. The Accounting Review, 90 (5), 1969-1994

EY (Ernst and Young) (2015).World Islamic Banking Competitiveness Report - Participation Banking, Available

Online on (The last access was 01-01-2016)

http://www.ey.com/GL/en/Industries/Financial-Services/fsoinsights-world-islamic,

Farley, J., \& Leavitt, H. (1968). A model of the distribution of branded personal products in Jamaica. Journal of Marketing Research, 5 (4), 362-368

Faraga, H., Mallin, C., \& Ow-Yonga, K. (2014). Corporate social responsibility and Financial Performance in

Islamic banks. Journal of Economic Behaviour and Organization, 103, 21-38

Farook, S., Hassan, K., \& Lanis, R. (2011). Determinants of Corporate Social Responsibility Disclosure: Case of

Islamic banks. Journal of Islamic Accounting and Business Research, 2 (2), 114 - 141

Farook, S. (2008). Social Responsibility for Islamic Financial Institutions: Laying Down a Framework. Journal of

Islamic Economics, Banking and Finance, 4 (1), 61-82

Ferraz, L., Fernandez, H., \& Louvel, P. (2011). Um 1'ndice d avaliac, a o da qualidade da governanc, a corporativa no

Brasil. R. Cont. Fin. - USP, Sa o Paulo, 22 (55), 45-63

Francis, J., Nanda, D., \& Olsson, P. (2008). Voluntary Disclosure, Earnings Quality, and Cost of Capital.

Journal of Accounting Research, 46(1), 53-99 
Galang, R. (2011). Victim or victimizer: Firm responses to Government Corporation. Journal of Management Studies. doi:10.1111/j.1467-6486.2010.00989.x.

Garcia-Castro, R., Arino, M., \& Canela, M. (2010). Does social performance really lead to financial Performance?

Accounting for endogeneity. Journal of Business Ethics, 92 (1), $107-126$

Gonza'lez, J., \& Garci'a-Meca, E. (2014). Does Corporate Governance Influence Earnings Management in Latin American Market. Journal of Business Ethics, 121, 419-440

Gopinath, T., Almahrog, Y., \& Aribi, Z. (2015). Female directors and earnings Management: Evidence from UK companies. International Review of Financial Analysis, 39 (C), 137-146

Grassa, R., \& Gazdar, k. (2013).Financial development and economic growth in GCC Countries, A Comparative study between Islamic and conventional finance. International Journal of Social Economics, 41 (6), 493-514

Gray, R., Kouhy, R. \& Lavers, S. (1995). Constructing a research database of social and Environmental Reporting by UK companies. Accounting, Auditing \& Accountability Journal, 8 (2), 78-101

Grougiou,V., Stergios L., Emmanouil D., \& Owusu-Ansahe, S. (2014). Corporate social responsibility and earnings

Management in U.S. banks. Accounting Forum, 38, 155-169

Guidry, R., \& Patten, D. (2012). Voluntary disclosure theory and financial control Variables: An Assessment of

Recent environmental disclosure research. Accounting Forum, $36,81-90$

Gujarati, D. (1995). Basic econometrics. New York: McGraw-Hill Hahn, R., \& Kuhnen, M. (2013). Determinants of sustainability reporting: A review of Results, trends, Theory and Opportunities in an expanding field of research. Journal of Cleaner Production, 59 (15), $5-21$ 
Hair, J., Black, W., Babin, B., Anderson, R. \& Tatham, R. (2006). Multivariate Data Analysis, 6 ed, Pearson

Educational International -Prentice Hall, Upper Saddle RiverNew Jersey

Hamdi, F., \& Zarai, M. (2012). Perspectives of Earnings Management in Islamic Banking Institutions.

International Journal of Business and Management Invention ISSN (Online): 2319 - 8028, ISSN (Print):2319- 801X

Haniffa, R. \& Hudaib, M. (2007). Exploring the ethical identity of Islamic banks via Communication in Annual

Reports. Journal of Business Ethics, 76, 97-116

Hassan, A., \& Harahap, S. (2010). Exploring corporate social responsibility disclosure: the Case of Islamic banks.

International Journal of Islamic and Middle Eastern Finance and Management, 3 (3), 203- 227

Hasan, Z. (2008). Corporate governance of Islamic financial institutions. Study Presented at the Conference on Malaysian Study of Islam, Lamperter, UK

Healy, P., \& Wahlen, J. (1999). A Review of the Earnings Management Literature and Its Implications for Standard

Setting. Accounting Horizons, 13, 365-383

Hillman, A., \& Keim, G. (2001). Shareholder value, stakeholder management and social Issues: What's the bottom

Line? Strategic Management Journal, 22 (2), 125-139

Hong, Y., \& Anderson, M. (2011). The Relationship between Corporate Social Responsibility and Earnings

Management: An Exploratory Study, Journal of Business Ethics, 104 (4), 461-471

Hossain, M., \& Hammami, H. (2009). Voluntary Disclosure in the Annual Reports of an Emerging Country: The case of Qatar. Advances in Accounting; Incorporating International Advances in Accounting, 25, 255-265 
Ibrahim, M., Yusoff, H., \& Darus, F. (2015). Are Socially Responsible Firms Managing Their Earnings?

Preliminary Evidence from an Emerging Market. Proceeding 2014 International Conference on Governance and Accountability, Edirne, Turkey

IFSB (The Islamic Financial Services Board) (2015). Available online on http://www.ifsb.org/ the last Access was

$$
\text { 01-01-2016 }
$$

Jensen, M. (2010). Value maximization, stakeholder theory, and the corporate Objective function. Journal of Applied

Corporate Finance, 14(3), 8-21.

Jizi, M., Salama, A., Dixon, R., \& Stratling, R. (2014). Corporate Governance and Corporate Social Responsibility

Disclosure: Evidence from the US Banking Sector. Journal of business ethics, 125, 601-615

Jo, H., \& Kim, Y. (2008). Ethics and disclosure: A study of the financial performance of firms in the Seasoned equity offerings market. Journal of Business Ethics, 80 (4), 855-878

Jobst, A., \& Andreas, A. (2007). The Economics of Islamic Finance and Securitization. IMF Working Paper No. $07 / 117$

Karim, R. (1990). The Independence of Religious and External Auditors: The Case of Islamic Banks. Accounting, Auditing and Accountability Journal, 3 (3)

Kanagaretnam, K., Krishnan, G., \& Lobo, G. (2010). an empirical analysis of auditor Independence in the banking industry. The Accounting Review, 85 (6), 2011-2046

Katmon, K., \& Al Farooque, O. (2015). Exploring the Impact of Internal Corporate Governance on the Relation between Disclosure Quality and Earnings Management in the UK Listed Companies. Journal of business ethics, 1-23, DOI $10.1007 / \mathrm{s} 10551-015-2752-8$ 
Kaufmann, D., Kraay, A., \& Mastruzzi, M. (2010). The worldwide governance indicators: A summary of methodology, data and analytical issues. World Bank Policy Research. Working Paper http://papers.ssrn.com/sol3/papers.cfm?abstract_id=1682130

Khediri, K., Charfeddine, L, \& Youssef, S. (2015). Islamic versus conventional banks in the GCC Countries: A

Comparative study using classification techniques. Research in International Business and Finance, 33, 75-98

Kim, Y., Park, M., \& Wier, B. (2012). Is earnings quality associated w ith corporate social responsibility?

The Accounting Review, 87 (3), 761-796

Kothari, S., Lcone, A., \& Wasley, C. (2005). Performance-Matched Discretionary Accruals. Journal of Accounting and Economics, 39, 163-197

Labelle, R., Gargouri, R., \& Francoeur, C. (2010). Ethics, diversity management and Financial Reporting quality.

Journal of Business Ethics, 93, 335-353

Leuz, C., Nanda, D., \& Wysocki, P. (2003). Earnings management and investor Protection: an International

Comparison. Journal of Financial Economics, 69 (3), 505-527

Leventis, S. (2001). Voluntary disclosure in a European Emerging capital market: the Case of the Athens stock

Exchange. Ph.D. Strathclyde University, UK

Li, J., Pike, R., \& Haniffa, R. (2008). Intellectual Capital Disclosure and Corporate Governance Structure in UK

Firms. Accounting and Business Research, 38 (2), 137-159

Maali, B., Casson, P., \& Napier, C. (2006). Social reporting by Islamic banks. Abacus, 42 (2), 266-289

Mahjoub, L., \& Khamoussi, H. (2013). Environmental and social policy and earning Persistence. Business Strategy and

The Environment, 22(3), 159-172 
Maghyereh, A., \& Awartani, B. (2014). Bank distress prediction: empirical evidence From the Gulf Cooperation

Council countries. Res. Int. Bus. Finance. 30, 126-147

Mallin, C., \& Michelon, G. (2011). Board Reputation Attributes and Corporate Social Performance: An Empirical

Investigation of the US Best Corporate Citizens. Accounting and Business Research, 41 (2), 119-144

Mashhour, N. (1996). Social and Solidarity Activity in Islamic Banks. International Institute of Islamic Thoughts, [inArabic]

McGuire, S., Omer, T., \& Sharp N. (2012). The impact of religion on financial reporting irregularities. The Accounting Review, 87 (2), 645673

Mitchell, R., Agle, B., \& Wood, D. (1997). Toward a theory of stakeholder identification and salience: Defining the

Principle of whom and what really counts. Academy of Management Review, 22 (4), 853-886

Obida, S., \& Demikha, L. (2011). Earning management: Islamic perspective. Asia Pacific Journal of Accounting and

Finance, 2 (1)

Olson D., \& Zoubi, T. (2008). Using accounting ratios to distinguish between Islamic and Conventional banks in

The GCC region. Int J Account, 43, 45-65

Owusu-Ansah, S., Leventis, S., \& Caramanis, C. (2010). The pricing of statutory audit services in Greece. Accounting Forum, 34(2), 139152

Prior, D., Surroca, J., \& Tribo, J., (2008). Are Socially Responsible Managers Really Ethical? Exploring Relationship

between Earnings Management and Corporate Social Responsibility. Corporate Governance, 16 (3), 160-177

Quttainah, M., Song, L., \& Wu, Q., (2013). Do Islamic Banks Employ Less Earnings Management. Journal of International Financial Management \& Accounting, 24 (3), 203-233 
Richardson, V. (2000). Information asymmetry and earnings management: Some Evidence. Review of Quantitative

Finance and Accounting, 15(4), 325-347

Roberts, R. (1992). Determinants of Corporate Social Responsibility Disclosure: An Application of Stakeholder

Theory. Accounting, Organizations and Society, 17 (6), 595612

Scholtens, B., \& Kang, F. (2013). Corporate social responsibility and earnings Management: Evidence from Asian

Economies. Corporate Social Responsibility and Environmental Management, 20 (2), 95-112

Scholtens, B. (2009). Corporate social responsibility in the international banking Industry. Journal of Business Ethics, 86(2), 159-175

Shen, C., \& Chih, H. (2005). Investor protection, prospect theory, and earnings Management: An International

Comparison of the banking industry. Journal of Banking \& Finance, 29, 2675-2697

Shu, P., \& Chiang, S. (2014). Firm Size, Timing, and Earnings Management of Seasoned Equity Offerings.

International Review of Economics and Finance, 29, 177-194. http://dx.doi.org/10.1016/j.iref.2013.05.011

Siddiqui, M. (2006). Islamic banking and finance in theory and practice: a survey of State of the art. Islamic Econ. Stud.

$13,1-48$

Srairi, S. (2010). Cost and profit efficiency of conventional and Islamic banks in GCC Countries. J. Prod. Anal. 34, $45-62$

Suchman, M., (1995). Managing legitimacy: Strategic and institutional approaches. Academy of Management review, 20

(3), 571-610 
Sun, N., Salama, A., Hussainey, K., \& Habbash, M. (2010). Corporate environmental disclosure, Corporate Governance and earnings management. Managerial Auditing Journal, 25 (7), 679-700

Thakur, S. (1996). Religion and Social Justice, St Martin's Press, New York, NY Usmani, T. (2002). An introduction to Islamic finance. Kluwer Law International, Hague, Netherlands Visser, H. (2009). Islamic Finance: Principles and Practice Cheltenham. Edward Elgar Publishing

Wang, Y., \& Campbell, M. (2012). Corporate governance, earnings management, and IFRS: Empirical Evidence from Chinese domestically listed companies. Advances in Accounting, incorporating Advances in International Accounting, 28, 189-192

Xie, B., Davidson, W., \& Dadalt, P. (2003). Earnings management and corporate governance: The roles of the board

and the audit committee. Journal of Corporate Finance, 9, 295-316

\section{Tables}

Table 1: Descriptive Statistics

$\begin{array}{lcccccc}\text { Variables } & \text { Minimum } & \text { Maximum } & \text { Mean } & \begin{array}{c}\text { Std. } \\ \text { Dev. }\end{array} & \text { Skewness } & \text { Kurtosis } \\ \text { CSRD } & 0.00 & 0.50 & 0.319 & 0.091 & -0.503 & 0.870 \\ \text { EM } & -2.191 & 0.000 & -1.013 & 0.240 & -1.063 & 11.451 \\ \text { SIZE } & 1.11 & 4.91 & 3.295 & 0.843 & -0.551 & -0.009 \\ \text { AGE } & 1.00 & 57.00 & 16.518 & 13.589 & 1.126 & 0.422 \\ \text { STAND } & 0.00 & 1.00 & 0.640 & 0.481 & -0.591 & -1.675 \\ \text { LEV } & 0.00 & 98.87 & 35.640 & 32.108 & 0.688 & -1.099 \\ \text { ROA } & -45.31 & 31.95 & 0.194 & 7.613 & -1.730 & 14.192 \\ \text { AC.E } & 0.00 & 1.00 & 0.829 & 0.377 & -1.773 & 1.162 \\ \text { AC.SIZE } & 0.00 & 5.00 & 2.681 & 1.380 & -0.947 & 0.014 \\ \text { B.IND } & 0.10 & 0.90 & 0.509 & 0.197 & 0.613 & -0.483 \\ \text { B.SIZE } & 5.00 & 16.00 & 9.084 & 1.937 & 0.314 & 0.815 \\ \text { B.MEET } & 1.00 & 12.00 & 5.544 & 1.793 & 0.677 & 1.752 \\ \text { SSB.R } & 0.00 & 1.00 & 0.805 & 0.397 & -1.563 & 0.448 \\ \text { SSB.CM } & 0.00 & 1.00 & 0.913 & 0.281 & -2.978 & 6.969 \\ \text { SSB.SIZE } & 1.00 & 9.00 & 3.827 & 1.215 & 1.025 & 1.374 \\ \text { CAP } & 8.37 & 137.76 & 28.450 & 24.774 & 2.343 & 5.430\end{array}$


Variable definition: $\mathbf{E M}=$ earning management measure; CSRD= corporate social responsibility disclosure score based on CSR index; B.IND=Board independence (ratio of the number of non-executive directors to tot al number of directors); B.SIZE= total number board members; B.MEET=number of BOD meeting within the year; AC.E $=$ dummy code 1 if there is audit Committee inside the Islamic banks or 0 otherwise; AC.SIZE=total number of audit committee; SBB.SIZE=total number of SSBM on the board; SSB.R= dummy code 1 if the SSBM are has membership in a credible Islamic institutions as AAOIFI or 0 otherwise; SSB.CM=dummy code 1 if SSB member with a cross membership in more than one Islamic bank or 0 otherwise; SIZE= natural logarithm of total assets; $\mathrm{ROA}=$ profitability ratio based on return on assets; STAND=dummy code 1 if the banks adopt AAOIFI/other Islamic standards or 0 otherwise; $L E V=l e v e r a g e$ ratio based on total liabilities for total assets; $\mathrm{CAP}=$ ratio of actual regulatory capital (Tier 1 capital) to the minimum required regulatory capital; Age= age of the bank

Table 2: Correlation Matrix

\begin{tabular}{|c|c|c|c|c|c|c|c|c|c|c|c|c|c|c|c|}
\hline $\begin{array}{l}\text { Variab } \\
\text { les }\end{array}$ & CSRD & $E M$ & $\begin{array}{c}S I Z \\
E\end{array}$ & $\begin{array}{l}S T A \\
N D\end{array}$ & $\overline{L E V}$ & $\overline{R O A}$ & $\overline{A C . E}$ & $\begin{array}{l}A C . \\
\text { SIZE }\end{array}$ & $\begin{array}{c}B . \\
I N D\end{array}$ & $\begin{array}{c}B . \\
\text { SIZE }\end{array}$ & $\begin{array}{c}B . \\
M E E T\end{array}$ & $\begin{array}{c}\text { SSB. } \\
\boldsymbol{R}\end{array}$ & $\begin{array}{c}\text { SSB. } \\
\text { CM }\end{array}$ & $\begin{array}{l}\text { SSB. } \\
\text { SIZE }\end{array}$ & $\overline{C A P}$ \\
\hline CSRD & 1.000 & $\begin{array}{l}\overline{0.1} \\
42\end{array}$ & $\begin{array}{c}- \\
0.20 \\
I^{*}\end{array}$ & 0.361 & 0.081 & 0.299 & 0.125 & 0.039 & 0.029 & 0.214 & $0.281^{* *}$ & 0.112 & 0.138 & 0.155 & 0.081 \\
\hline$E M$ & & $\begin{array}{l}1.0 \\
00\end{array}$ & $\begin{array}{c}0.19 \\
5^{\circ}\end{array}$ & 0.024 & 0.038 & 0.232 & 0.130 & -0.127 & 0.079 & 0.100 & -0.039 & 0.143 & $\hat{0.163}$ & $\tilde{0.092}$ & 0.043 \\
\hline SIZE & & & $\begin{array}{c}1.00 \\
0\end{array}$ & 0.360 & 0.353 & 0.200 & 0.089 & 0.028 & 0.339 & 0.050 & $0.249^{\circ *}$ & 0.172 & 0.009 & 0.040 & 0.461 \\
\hline STAND & & & & 1.000 & 0.438 & 0.178 & 0.020 & -0.119 & 0.117 & 0.154 & 0.003 & 0.346 & 0.230 & 0.279 & 0.365 \\
\hline LEV & & & & & 1.000 & 0.039 & 0.170 & $0.270^{* *}$ & 0.137 & 0.170 & $0.363^{* *}$ & 0.107 & 0.076 & 0.313 & 0.661 \\
\hline$R O A$ & & & & & & 1.000 & 0.088 & 0.148 & 0.061 & 0.061 & 0.079 & 0.068 & 0.006 & 0.103 & 0.076 \\
\hline AC.E & & & & & & & 1.000 & $0.632^{* *}$ & 0.044 & 0.203 & 0.037 & 0.244 & 0.014 & 0.018 & 0.259 \\
\hline $\begin{array}{l}\text { AC.SIZ } \\
E\end{array}$ & & & & & & & & 1.000 & 0.035 & 0.323 & 0.047 & 0.117 & 0.121 & 0.322 & $0 . \overline{413}$ \\
\hline B.IND & & & & & & & & & 1.000 & 0.281 & 0.085 & 0.382 & 0.318 & 0.238 & 0.268 \\
\hline B.SIZE & & & & & & & & & & 1.000 & $0.240^{\circ *}$ & 0.169 & 0.002 & 0.320 & $\dot{0.085}$ \\
\hline $\begin{array}{l}\text { B.MEE } \\
T\end{array}$ & & & & & & & & & & & 1.000 & 0.124 & 0.081 & 0.108 & 0.268 \\
\hline SSB.R & & & & & & & & & & & & 1.000 & 0.565 & 0.003 & 0.113 \\
\hline $\begin{array}{l}S S B . C \\
M\end{array}$ & & & & & & & & & & & & & 1.000 & 0.164 & 0.082 \\
\hline $\begin{array}{l}S S B . S I \\
Z Z E\end{array}$ & & & & & & & & & & & & & & 1.000 & 0.638 \\
\hline $\begin{array}{l}\text { CAP } \\
\text { VAriable } \\
\text { (ratio of } \\
\text { year; AC } \\
\text { SSBM o } \\
\text { SSB me } \\
\text { on asset } \\
\text { CAP ra } \\
\text { "Statisti }\end{array}$ & $\begin{array}{l}\text { efinition: } \\
\text { e numbe } \\
\text { =dumm } \\
\text { he board } \\
\text { er with a } \\
\text { STAND= } \\
\text { of actual } \\
\text { significa }\end{array}$ & $\begin{array}{l}\text { lator } \\
\text { lat con }\end{array}$ & $\begin{array}{l}\text { mmy cership } \\
\text { ersif } \\
1 \text { ip } \\
\text { capital }\end{array}$ & $\begin{array}{l}\text { lement } \\
\text { ectors t } \\
\text { it Comn } \\
\text { e } 1 \text { if th } \\
\text { more th } \\
\text { banks a } \\
\text { ier } 1 \text { cap }\end{array}$ & $\begin{array}{l}\text { asure; } \\
\text { ot al nu } \\
\text { tee insid } \\
\text { SSBM a } \\
\text { one Isla } \\
\text { pt AAO } \\
\text { al) to the }\end{array}$ & $\begin{array}{l}\text { RD= co } \\
\text { ber of d } \\
\text { the Islan } \\
\text { has men } \\
\text { ic bank } \\
\text { Fi//other } \\
\text { ninimum }\end{array}$ & $\begin{array}{l} \\
\text { orate soc } \\
\text { ectors); } \\
\text { c banks o } \\
\text { earship in } \\
0.0 \text { otherw } \\
\text { lamic sta } \\
\text { equired r r } \\
\text { el; ***:Ste }\end{array}$ & $\begin{array}{l}\text { Irespons } \\
\text { IZE= tot } \\
\text { otherwi } \\
\text { credible } \\
\text {; SIZE } \\
\text { lards or } \\
\text { lalatory ce } \\
\text { tical sign }\end{array}$ & $\begin{array}{l}\text { lity disc } \\
\text { lumber } \\
\text { uC.SIZ } \\
\text { amic ins } \\
\text { tural log } \\
\text { therwise } \\
\text { tal; Age } \\
\text { cance at }\end{array}$ & $\begin{array}{l}\text { ure scor } \\
\text { ard men } \\
\text { total nu } \\
\text { utions a } \\
\text { ithm of } \\
\text { LEV=lev } \\
\text { age of th } \\
\text { \% level }\end{array}$ & $\begin{array}{l}\text { based on } \\
\text { ers; B.M } \\
\text { er of aud } \\
\text { AlOIFI } \\
\text { al assets; } \\
\text { age ratio } \\
\text { ank }\end{array}$ & $\begin{array}{l}R \text { index } \\
T=\text { numb } \\
\text { committ } \\
\text { otherw } \\
\text { OA= pro } \\
\text { sed on }\end{array}$ & $\begin{array}{l}\text { B.IND=B } \\
\text { of BOD } \\
\text { ofBB.SI } \\
\text {; SSB.CN } \\
\text { ability ra } \\
\text { al liabilit }\end{array}$ & $\begin{array}{l}\text { ard inde } \\
\text { reeting } \\
=\text { =total n } \\
\text { dummy } \\
\text { o based } \\
\text { s for tot }\end{array}$ & $\begin{array}{l}1.000 \\
\text { ndence } \\
\text { hin the } \\
\text { nber of } \\
\text { ode } 1 \text { if } \\
\text { return } \\
\text { assets; }\end{array}$ \\
\hline
\end{tabular}


Table 3: Results of 2SLS estimation

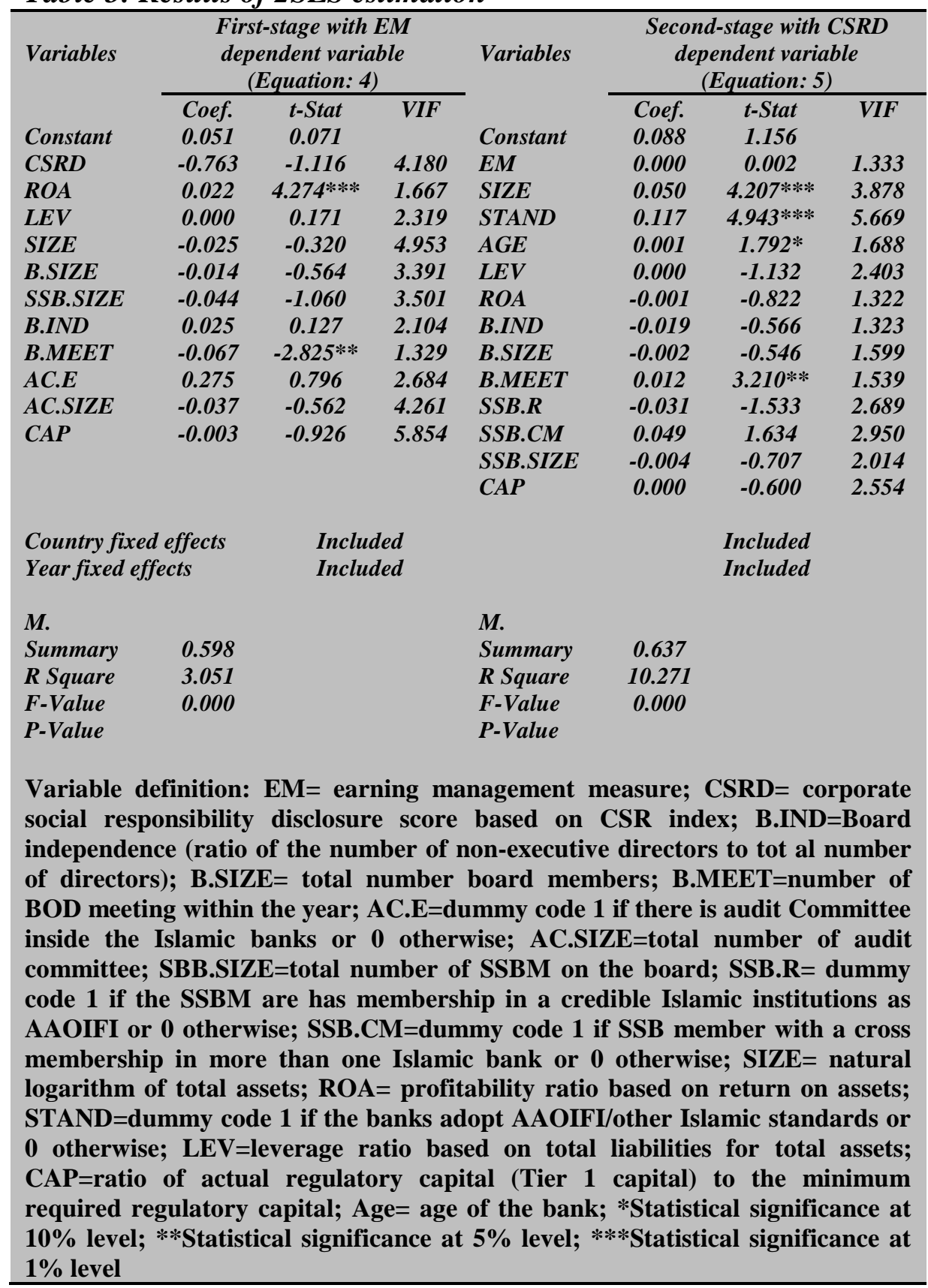

